\title{
SURAU DAN TRADISI PERNASKAHANISLAM DI MINANGKABAU: \\ Studi atas Dinamika Tradisi Pernaskahan di Surau- surau di Padang dan Padang Pariaman*
}

\section{Pramono}

\author{
Universitas Andalas, Jl. Kampus Limau Manis Padang
} e-mail: Pramonofsua@yahoo.co.id

\begin{abstract}
Surau is a traditional institution of education in Minangkabau which has important role in developing Islam. In Islamic local discourse, surau became a center of order ( $t$ arîkah), the center for excellenceand for defending to criticize the another untrue ideology of Islam. In this context, syaikh from each surau write the manuscript to critisize the untruth ideology of Islam or social condition. There are four surau located in Padang and Padang Pariaman where many manuscripts can be found. The manuscripts are culturally important since they are related to the daily religious needs of the disciples of the order of Syattariyah in both places. This is related to the beliefs that to know about the guru, to posses the book, or to listen to the stories about the ulema, the guru of the order of Syattariyah are essential. Besides, the manuscripts are written to criticize opinions of the other Islamic schools whichare not appropriate according to the writer's Islamic perception.
\end{abstract}

إن الخلوة عبارة عن مؤسسة تربوية تقليدية فى مينانكابو والتى تلعب دورا

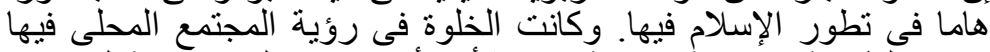

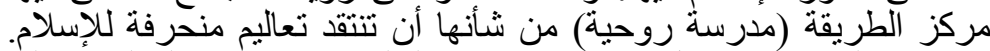

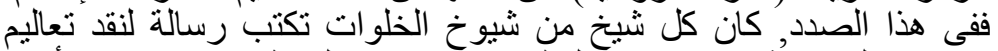

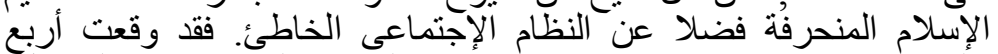

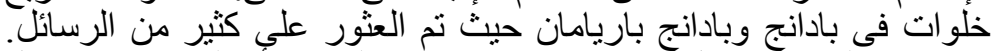

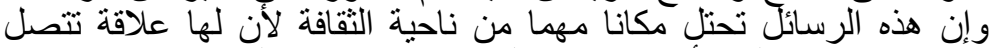

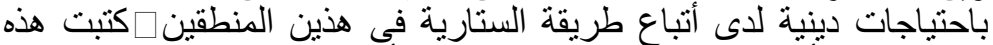

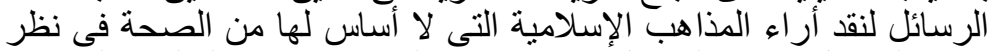

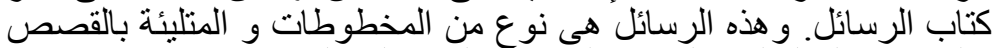

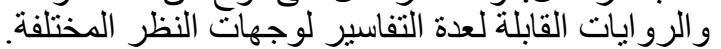

Kata Kunci: tradisi pernaskahan Islam, surau, tarekat Syattariyah, Minangkabau 


\section{PENDAHULUAN}

Minangkabau merupakan sukubangsa di Indonesia yang mendiami sebagian besar wilayah Provinsi Sumatera Barat. Etnis ini memiliki karakteristik yang unik, dalam hal hubungan antara sosiokultural dengan Islam, dibandingkan sukubangsa-sukubangsa yang lain di Indonesia. Oleh karena itu, topik mengenai hubungan sosialkultural dan Islam di Minangkabau tetap menarik untuk dikaji.

Dalam konteks hubungannya dengan Islam, di Minangkabau dikenal salah satu lembaga Islam yang penting. Lembaga tersebut adalah surau, yaitu sebuah lembaga pribumi yang telah menjadi pusat pengajaran Islam yang menonjol. Surau juga merupakan titik tolak Islamisasi di Minangkabau. Sebagai pusat tarekat, surau juga menjadi benteng pertahanan Minangkabau terhadap berkembangnya dominasi kekuatan Belanda (Azra, 2003:34). Selain itu, sebagai pusat tarekat, surau juga menjadi tempat untuk konsentrasi gerakan bagi masingmasing golongan yang sedang berpolemik tentang paham keislaman yang terjadi di Minangkabau pada akhir abad ke-19 sampai awal abad ke-20.

Dalam fungsinya yang terakhir di atas, pada waktu itu surau menjadi institusi penting dalam proses transmisi berbagai pengetahuan Islam. Di surau itulah para ulama dari masing-masing kubu membangun jaringan guru-murid sehingga tercipta saling-silang hubungan keilmuan yang sangat kompleks. Seiring dengan persebaran paham keagamaan Islam di surau-surau tersebut, tradisi penulisan dan penyalinan naskah pun tumbuh dengan subur. Para syaikh, ulama, buya, dan ungku yang mengajar di suatu surau, menyalin dan menulis naskah.

Surau sebagai tempat penulisan dan penyalinan naskah merupakan fenomena yang menarik sebagai gambaran tradisi pernaskahan di Minangkabau. Lebih menarik lagi, tradisi pernaskahan tersebut masih berlangsung hingga akhir abad ke-20 bahkan sampai sekarang. Dalam hal ini misalnya, dikenal Imam Maulana Abdul Manaf Amin al-Khatib (lahir 18 Agustus 1922), sebagai penyalin dan penulis naskah yang masih aktif dalam memproduksi manuskrip di surau Nurul Huda, Padang. Beliau banyak menulis dan menyalin naskah yang berisi teks sejarah, hikayat, dan ajaran tarekat Syattariyah (Pramono, 2005 dan 2006). 
Sebagai sebuah tradisi yang berlangsung cukup lama, tidak mengherankan jika tradisi pernaskahan di Minangkabau itu telah meninggalkan artefak budaya berupa naskah kuno (manuscript) dengan jumlah yang cukup banyak. Naskah-naskah tulisan tangan (manuscript) tersebut mengandung teks tertulis mengenai berbagai pemikiran, pengetahuan, keislaman, sastra, pengobatan, serta perilaku masyarakat masa lalu. Naskah-naskah tersebut tersimpan di beberapa surau dengan kondisi yang beragam, dari kondisi naskah yang cukup baik (naskah dapat dibaca) hingga naskah dalam kondisi rusak, dengan kerusakan yang cukup parah (naskah tidak bisa dibaca lagi, hancur).

Hal itu dapat dilihat dari katalogus-katalogus: $\mathrm{Ph}$. S van Ronkel (1908 A, 1908 B, 1909, 1913, 1912, 1946), katalogus Amir Sutarga dkk. (1972), katalogus yang diusahakan bersama oleh M.C. Ricklefs dan P Voorhoeve (1977), serta katalogus yang dikompilasioleh E.P. Wierenga (1998), dua katalogus yang tampaknya juga didasarkan kepada karya $\mathrm{Ph}$. S van Ronkel, semakin membuktikan hal itu. Berdasarkan katalogus-katalogus yang memuat naskah Melayu dan Minangkabau yang ada, Zuriati (2003:1) menghitung ada 371 naskah Minangkabau yang berada di luar Sumatera Barat. Sebagian besar di antaranya hingga pada saat ini berada di luar negeri dengan rincian: 261 naskah berada di negeri Belanda, 102 naskah di Inggris, 19 naskah di Jerman Barat, dan 1 naskah berada di Malaysia. Selebihnya, 78 naskah, berada di Indonesia, yaitu di Perpustakaan Nasional Jakarta. Berangkat dari data-data itu, terlihat bahwa jumlah naskah Minangkabau yang terdapat di beberapa surau di Padang dan Padang Pariaman menempati posisi kedua terbanyak di dunia setelah Belanda.

Tradisi pernaskahan di Minangkabau masih berlangsung hingga sekarang sehingga dapat dipastikan jumlah naskah yang disebutkan di atas dapat bertambah. Kondisi seperti ini memperlihatkan bahwa sebagai sukubangsa yang terkenal dengan tradisi lisannya yang sangat kental, ternyata Minangkabau memiliki tradisi pernaskahan yang cukup maju. Hal ini terjadi karena melalui keberadaan dan peran suraulah, tradisi penulisan naskah-naskah keagamaan yang telah berumur ratusan tahun tersebut tetap berlangsung. Kondisi ini tentu saja berbeda dengan fenomena di wilayah lain, dimana tradisi penulisan naskah tidak lagi berkembang. 
Dengan demikian, keberadaan naskah-naskah di Minangkabau sebagai hasil dari tradisi pernaskahan merupakan khasanah budaya yang penting dan menarik untuk dikaji, setidaknya bila dipandang dari dua hal, yaitu:pertama, tradisi pernaskahan di Minangkabau merupakan sebuah kegiatan intelektual dalam masyarakat tradisional (local genius); dankedua, sebagai sebuah produk budaya, naskahnaskah Minangkabau merupakan gambaran berbagai bentuk ungkapan masyarakat, dengan bahasanya masing-masing. Pada konteks ini umumnya, artikulasi satu masyarakat bahasa, dan masa tertentu akan berbeda dengan artikulasi masyarakat bahasa, dan masa lainnya, kendati pada mulanya mereka membaca teks yang sama, sehingga dengan demikian muncul dinamika yang sedemikian unik. Lebih jauh, kaitannya dengan Islam, dari naskah-naskah Minangkabau akan memberikan data yang sangat kaya mengenai dinamika Islam di daerah tersebut.

Penelitian ini menjelaskan dinamika tradisi pernaskahan di Minangkabau, khususnya di surau-surau di Padang dan Padang Pariaman. Akan tetapi, karena untuk mengetahui adanya dinamika tersebut diperlukan data yang menginformasikan latar belakang yang diyakini menjadi permulaan dari tradisi pernaskahan di Minangkabau, maka pembahasan atas sejarah penciptaan naskah-naskah melalui kajian filologi dengan memperhatikan data tekstual dipandang penting. Di samping itu, kajian sejarah sosial intelektual juga diperlukan untuk melihat proses sosial-kultural yang mempengaruhi dinamika tradisi pernaskahan di Minangkabau secara umum, dan di Padang dan Padang Pariaman secara khusus.

Surau-surau yang terdapat di Padang dan Padang Pariaman dipilih sebagai latar studi karena setidaknya ada tiga alasan, yaitu:pertama, di beberapa surau di Padang dan Padang Pariaman memiliki koleksi naskah yang cukup banyak dibandingkan dengan surau-surau lainnya di wilayah Minangkabau. Hal ini mengindikasikan bahwa pada surau-surau di kedua daerah itu pernah berlangsung dinamika tradisi pernaskahan yang signifikan;kedua, hingga kini, tradisi pernaskahan (penyalinan dan penulisan naskah) dalam bahasa Melayu Minangkabau dengan menggunakan aksara Jawi (Arab Melayu) di kedua daerah itu masih berlangsung di beberapa suraunya, khususnya di Padang; danketiga, belum dilakukannya penelitian secara lebih menyeluruh tentang surau dengan 
dinamika tradisi pernaskahannya di Minangkabau, khususnya di daerah Padang dan Padang Pariaman. Dengan demikian penelitian ini juga dimaksudkan untuk mengisi kekosongan atau kurangnya studi tentang dinamika tradisi pernaskahan di Minangkabau, di mana surau sebagai pusatnya.

\section{TEMUAN NASKAH DI SURAU-SURAU DI PADANG DAN PADANG PARIAMAN}

\section{Surau di Padang}

Di Padang terdapat dua surau yang di dalamnya ditemukan puluhan naskah. Kedua surau tersebut adalah surau Nurul Huda dan Surau Paseban. Berikut ini gambaran dari kedua surau itu dan naskahnaskah yang terdapat di dalamnya.

Surau Nurul Huda

Surau Nurul Huda terdapat di Koto Tangah, Tabing, Padang. Dalam konteks tradisi pernaskahan di Minangkabau surau ini menjadi menarik dan penting untuk dijelaskan. Hal ini karena di surau ini, tradisi penulisan naskah masih berlangsung hingga akhir tahun 2006. Naskah-naskah yang terdapat di surau ini ditulis oleh Imam Maulana Abdul Manaf Amin al-Khatib (w. 2006). Ulama ini yang banyak menulis dan menyalin naskah tentang sejarah dan ajaran tasawuf berdasarkan paham tarekat Syattariyah.

Imam Maulana Abdul Manaf Amin al-Khatib adalah penyalin dan penulis naskah yang sangat produktif. Ia telah banyak menulis dan menyalin naskah.Hingga sekarang naskah yang telah ditulis dan disalinnya mencapai lebih kurang 22 karya (manuskrip). Imam Maulana Abdul Manaf Amin al-Khatib adalah seorang ulama dari golongan Kaum Tua (penganut tarekat Syattariyah). Tentang riwayat hidup Imam Maulana Abdul Manaf Amin al-Khatib, juga dapat dilihat dalam naskah otobiografinya berjudul Kitab Riwayat Hidup Imam Maulana Abdul Manaf Amin, yang selesai ditulis pada 28 Syawwal 1423 H/9 Nopember 2002 di suraunya sendiri, yaitu Surau Nurul Huda yang terletak di seberang Air Batang Kabung, Koto Tangah Tabing, Padang.

Dalam konteks tradisi penyalinan naskah-naskah Islam di Minangkabau, sosok Imam Maulana Abdul Manaf Amin al-Khatib dan karya-karyanya menjadi penting karena:pertama,Imam Maulana 
Abdul Manaf Amin al-Khatib adalah satu-satunya saksi dan narasumber yang dapat memberikan informasi tentang sebuah tradisi penyalinan dan penulisan naskah di Minangkabau yang masih berlanjut hingga saat ini. Di mana di wilayah lain (kecuali Bali), sudah tidak ditemukan tradisi seperti ini, yaitu tradisi penulisan dan penyalinan naskah; dan kedua,dari karya-karyanya dapat dilihat gambaran berbagai bentuk ungkapan masyarakat — dengan bahasanya masing-masing - atas teks-teks yang ia baca. Pada umumnya, artikulasi satu masyarakat bahasa, dan masa tertentu akan berbeda dengan artikulasi masyarakat bahasa, dan masa lainnya, kendati pada mulanya mereka membaca teks yang sama, sehingga dengan demikian muncul dinamika yang sedemikian kaya atas teks tersebut. Lebih jauh, kaitannya dengan Islam, naskah-naskah lokal tersebut akan memberikan data yang sangat kaya mengenai dinamika Islam di masing-masing daerah.

Hal lain yang juga penting adalah bahwa keberadaan naskahnaskah di atas menjadi penting untuk melihat bagaimana tradisi intelektual keislaman di Minangkabau. Naskah-naskah itu ditulis di surau yang para ulamanya terlatih berdiskusi dan berdebat. Sehingga, naskah-naskah itu merupakan saksi dari proses perdebatan dan polemik keagamaan yang terjadi di Minangkabau.

Abdul Manaf wafat di usia 84 tahun, tepatnya pada 12 Oktober 2006 di Rumah Sakit Selasih, Padang. Sebelum wafat ia sempat dirawat di rumah sakit tersebut karena penyakit yang dideritanya. Jasadnya di kuburkan di gobah (bangunan yang di dalamnya terdapat kuburan para guru, syaikh, ungku, dan para guru yang dihormatiyang terdapat di lingkungan Pesantren Madrasah Tarbiyah Islamiah (PMTI) di Batang Kabung, Padang). Kuburannya bersebelahan dengan kuburan Syaikh Haji Salif Tuanku Sutan atau yang juga dikenal dengan sebutan Ungku Batang Kabung oleh penduduk Koto Tangah, Padang.

Proses kreatif dalam penulisan naskah dimulai Abdul Manaf saat berusia 14 tahun. Sebagaimana disebutkan di atas, di usia itu ia sedang menuntut ilmu kepada Syaikh Paseban di Surau Paseban, Koto Panjang, Padang. Pada saat belajar kepada Syaikh Paseban itulah terdorong di dalam dirinya untuk menulis naskah. Hal ini didukung oleh koleksi naskah-naskah kitab agama, seperti kitab tafsir, nahwu 
syaraf, tasawuf, fiqih, mantiq ma'ani, dan juga naskah-naskah sejarah yang dimiliki Syaikh Paseban.

Naskah pertama yang ditulis oleh Abdul Manaf adalah naskah yang berjudul Inilah Sejarah Ringkas Auliyah Allah Asalihin Syaikh Abdurrauf (Syaikh Kuala) Pengembang Agama Islam di Aceh, yang disalin pada tahun 1936. Keterangan ini dapat ditemukan dalam naskah itu seperti kutipan berikut ini:

\footnotetext{
Adapun buku sejarah Syaikh Abdurrauf ini saya salin dahulu di Surau Paseban pada tahun 1936 Masehi dari buku kepunyaan Syaikh Paseban seorang ulama besar di Minangkabau yang waktu itu beliau telah berumur 120 tahun (seratus dua puluh tahun). Surau Paseban terletak di kampung Koto Panjang Koto Tangah Padang" (Amin, 1936:3).
}

Dalam perkembangan selanjutnya, penulisan naskah yang dilakukan Abdul Manaf tidak hanya di surau Paseban saja, tetapi juga di surau-surau lain tempatnya belajar. Kreatifitas penulisan naskah berlanjut di tempat tinggalnya, yaitu di Surau Nurul Huda hingga akhir hidupnya. Beberapa karyanya diselesaikan dengan cara dicicil dan dijadikan semacam hand out untuk diajarkan kepada muridmuridnya atau untuk bahan pengajian yang disampaikan kepada umat atau kaumnya. Dari beberapa hand out tersebut nantinya digabungkan dan menjadi sebuah karya yang utuh. Berikut ini dapat dilihat gambar Abdul Manaf pada saat menulis naskah.

Hingga akhir hidupnya Abdul Manaf telah menulis naskah tidak kurang dari 22 judul naskah. Berikut ini adalah judul-judul naskah yang ia tulis: (1) Sejarah Ringkas Aulia Allah as-Salihin Syaikh Burhanuddin Ulakan; (2) Inilah Sejarah Ringkas Auliah Allah asSalihin Syaikh Abdurrauf (Syaikh Kuala), Pengembang Agama Islam di Aceh; (3) Sejarah Ringkas Syaikh Paseban al-Syatari Rahimahulallahu Taala; (4) Kitab Menerangkan Perkembangan Agama Islam di Minangkabau Semenjak Dahulu dari Syaikh Burhanuddin sampai ke Zaman Kita Sekarang; (5) Kitab Fadlilati lSyuhur (Jilid I); (6) Kitab Fadlilati l-Syuhur (Jilid II); (7) Kitab Fadlilati l-Syuhur (Jilid III); (8)Kitab Fadlilati l-Syuhur (Jilid IV); (9) Sejarah al-Husin bin Ali Karimallahu Wajhahu; (10)Risalat Mauzatu l-Hasanah; (11) Sejarah Ringkas Syaikh Muhamad Nasir (Syaikh Surau Baru); (12)Kitab al-Takwim (Menerangkan Masalah Bilangan Takwim dan Puasa); (13) al-Risalah Tanbih al-Masyi; (14) Risalah 
Mizan al-Qalb untuk Bahan Pertimbangan bagi Kaum Muslimin Buat Beramal Ibadah Kepada Allah; (15) Risalah Sabilaturrisad Pedoman Kita Mengerjakan Amal Ibadah Menurut Syari'at Tauhid dan Haqiqat; (16)Kitab untuk Menyelenggaran Mayi; (17)Kitab Ziarah; (18) Kisah Mi'raj Nabi Muhammad (Terjemahan dari Dardil, 'Perjalanan Nabi); (19) Kitab Riwayat Hidup Haji Imam Maulana Abdul Manaf Amin al-Khatib; (20) Kitab Tahqiq (Menerangkan Pengajian Tarekat Syattari); (21) Kitab Nur al-Haqiqah (Menerangkan Pengajian Ilmu Tasawuf); dan (22)Keterangan Sejarah Kampung Batang Kabung dan Sejarah Tampat Batu Singka.

Pada saat ini yang diberi kepercayaan untuk menjaga kelestarian naskah-naskah karya Abdul Manaf adalah salah seorang keponakannya yang bernama Dar Yung Tongki. Sebelum meninggal, menurut Syafrizal, Abdul Manaf berpesan bahwa jika ada orang yang berkeinginan memfotokopi naskah, orang tersebut tidak boleh membawa yang asli. Pihak keluarga, khususnya keponakannya yang akan memfotokopikan, dan yang asli harus dikembalikan ke tempatnya semula. Dengan demikian, naskah-naskah karya Abdul Manaf sampai hari ini masih mudah diakses (Wawancara).

\section{Surau Paseban}

Surau Paseban terletak di Kelurahan Koto Panjang Ikua Koto, Kecamatan Koto Tangah, Padang. "Paseban" artinya tidak sama dengan "pasebanan" dalam bahasa Jawa, yang artinya tempat, atau balai pertemuan. "Paseban" di sini berarti tanah bekas penjara. "Penjara" maksudnya bukanlah penjara yang difungsikan sebagai kurungan bagi yang sedang menjalani hukuman. Namun, penjara di sini artinya tempat isolasi atau tempat berdiam diri bagi murid-murid yang sedang berusaha menjalani proses penyempurnaan ilmu agama, seperti suluk. Dalam mempelajari suluk, setiap murid dituntut untuk berkonsentrasi secara penuh, apabila mereka melakukan kesalahan sekecil apapun bentuknya, maka mereka harus mengulangi proses itu dari awal lagi (Putra, 2006).

Surau Paseban, berdiri di atas tanah seluas kira-kira 500 Meter persegi, dan sekelilingnya terhampar sawah-sawah yang luas. Di halaman depan terdapat kolam ikan yang berbentuk persegi pajang dan berukuran $\pm 11 \times 7 \mathrm{M}$, dan di halaman belakang terdapat sebidang kebun yang ditanami berbagai macam jenis sayuran. Masih di lokasi 
itu, berdiri pula "Surau Laki-Laki". Walaupun namanya surau, "Surau Laki-Laki" hanya berfungsi sebagai tempat tinggal/bermalam bagi kaum lelaki yang sedang menjalani pendidikan di Paseban, sedangkan untuk beribadah dan belajar tetap dilaksanakan di Surau Paseban. Di Surau Paseban sendiri, tidak hanya kaum laki-laki yang belajar di sana, tetapi juga kaum perempuan. Tidak ada jadwal pasti dalam belajar, terkadang bisa sampai larut malam.Itulah alasannya mengapa didirikan "Surau Laki-Laki", sedangkan murid perempuan yang kemalaman bisa tidur di Surau Paseban.

Di Surau Paseban tersimpan 25 naskah yang seluruhannya ditulis dengan aksara Arab, dan berbahasa Arab. Naskah-naskah tersebut terdiri atas 5 versi kitab Tafsir Alquran termasuk kitab Ini Tafsir Ghãrbi Al-Qur'an, kitab Ma'ani, kitab Ilmu Bayan, Bádiq, Ma'ani, kitab Mantiq, kitab Tauhid, 6 versi kitab fiqih termasuk diantaranya adalah salinan dari kitab karangan Yahya Mahyudin Abu Zahir Ibnu Sarakun Nawawi, kitab Syahrul Minhaz, kitab Jraraj, kitab Sarah Minhaj,kitab Al-Bahri, kitab Cerita Nabi Adam, serta 4 versi kitab Nahwu, dan ada beberapa kitab pengobatan. (Yusuf, et.al., 2004. Putra, 2004 dan 2006). Jumlah ini bisa lebih banyak lagi, jika kita berpedoman kepada keterangan Buya Imam Maulana Abdul Manaf Amin Al-Khatib, salah seorang murid Syaikh Paseban (w.1817-1935 M.), yang mengatakan bahwa sepeninggal Syaikh Paseban, banyak manuskrip-manuskrip tersebut yang "di bawa ke luar" atau dipinjam oleh berbagai orang, dan tidak dikembalikan, yang jumlahnya bisa mencapai 100-an manuskrip. Manuskrip-manuskrip tersebut, keseluruhannya merupakan salinan Syaikh Paseban dari kitab-kitab guru-gurunya. Dari sumber yang ada, tercatat beberapa orang ulama yang pernah menjadi guru Syaikh Paseban. Diantaranya yaitu Syaikh Habibullah di Ulakan (Khalifah VI Syaikh Burhanuddin Ulakan), Syaikh Malalo Limo Puluah di Malalak, Syaikh Surau Gadang Pakandangan, dan Syaikh Padang Gantiang. Selain itu, Syaikh Paseban diketahui juga aktif menyalin kitab-kitab milik Syaikh Muhammad Natsir/Syaikh Surau Baru (Putra, 2004 dan 2006).

\section{Surau di Padang Pariaman}

Padang Pariaman merupakan wilayah penting dalam hal penyebaran Islam di Sumatera Barat. Daerah ini diyakini oleh banyak pihak sebagai asal mula masuknya Islam di Sumatera Barat. 
Keyakinan tersebut tampak dalam ungkapan adat: adat dibawa turun, syarak dibawa naiak 'adat dibawa turun, syarak dibawa naik'. Ungkapan ini bermakna bahwa adat Minangkabau itu dikembangkan dari daerah Darek (Pagaruyung) dan Syarak dikembangkan dari daerah rantau (Pariaman) ke daratan.

Salah satu bukti bahwa Padang Pariaman pernah menjadi pusat keislaman di Minangkabau adalah banyaknya surau yang terdapat di daerah ini. Setaip nagari memiliki surau nagari dan surau-surau suku. Di surau-surau itulah kegiatan keagamaan dilakukan. Oleh karena itu, surau menjadi bagian penting dalam pengembangan keislaman di wilayah Padang Pariaman.

Dalam konteks tradisi pernaskahan, penulis menemukan dua buah surau yang di dalamnya pernah hidup tradisi pernaskahan, yaitu surau Gadang Ampalu dan surau Gadang Tandikek. Di kedua surau ini ditemukan banyak naskah hasil salinan dan tulisan para syaikh yang pernah memimpin surau. Berikut ini gambaran kedua surau itu dan deskripsi naskah-naskah yang ada di dalamnya.

\section{Surau Gadang Ampalu}

Surau Gadang Ampalu atau sekarang diberi nama Mesjid Raya VII Koto Ampalu terdapat di Nagari VII Koto, Kecamatan Sungai Sarik, Kabupaten Padang Pariaman. Surau ini merupakan surau penting yang terdapat di Padang Pariaman karena merupakan surau yang dijadikan tempat penyelesaian masalah keagamaan. Oleh karena itu surau ini disebut juga sebagai 'mahkamah syariat'.

Di surau ini ditemukan banyak naskah yang kondisinya sudah banyak yang sudah rusak. Jumlah naskah yang kondisinya sudah rusak diperkirakan berjumlah 30-an naskah. Semua naskah yang ada beralaskan kertas Eropa. Hanya satu naskah yang kondisinya masih utuh, yaituAlquran tulis tangan. Naskah ini memiliki ukuran naskah $20,7 \times 33 \mathrm{~cm}$; blok teks $11,7 \times 20,5 \mathrm{~cm}$; jilidan kuras: terdiri dari 17 kuras yang masing-masing kuras terdiri dari 12 lembar; tanpa penomoran hlm.; 408 hlm.; 15 baris tiap hlm.; tinta hitam dan merah; tulisan Arab; bahasa Arab; cap kertas: D \& C BLAUW; tanpa sampul.Kondisi naskah: Tulisan pada naskah dibingkai dengan dua buah garis dengan warna tinta merah. Naskah ini tidak lengkap, ada beberapa lembar yang hilang. Bagian pertama yang tersisa dimulai 6 ayat terakhir Surat al-Baqarah. Pada 24 lembar pertama sobek di pinggirnya. 


\section{Surau Gadang Tandikek}

Surau Gadang Tandikek atau yang sekarang dinamakan Mesjid Raya Mudiak Padang, beralamat di Nagari Tandikek, Kecamatan Patamuan, Kabupaten Padang Pariaman. Surau ini sampai sekarang menjadi pusat kegiatan keislaman di nagari Tandikek. Surau ini juga dijadikan pusat untuk penyelesaian masalah agama dan adat yang terjadi di nagari Tandikek.

Tradisi pernaskahan di surau Tandikek pernah hidup dan cukup maju. Hal ini dapat dilihat dari naskah-naskah yang ditemukan di surau tersebut. Berikut ini naskah-naskah yang terdapat di surau Tandikek. Naskah-naskah yang ditemukan di surau ini adalah: (1) tiga buah naskah yang berisi teks Alquran;(2) Ini Khutbah Hari Raya Adha; (3) Kitab Fikih; (4) Kitab Fikih (Sholat, Saksi Nikah, dan Qisas); dan (5) Kitab Nahwu.

\section{FAKTOR-FAKTOR YANG MELATARBELAKANGI HIDUPNYA TRADISI PERNASKAHAN}

Dari penelitian yang dilakukan ditemukan beberapa faktor yang diyakini menjadi latar belakang tumbuhnya tradisi pernaskahan di surau-surau di Padang dan Padang Pariaman. Faktor-faktor yang dimaksud adalah: (1) faktor perbedaan paham keislaman; (2) faktor sosial budaya; (3) faktor kondisi sosial-politik semasa; dan (4) faktor pendidikan surau.

\section{Faktor Perbedaan Paham Keislaman}

Dalam konteks keislaman lokal di Minangkabau, surau memainkan peranan penting dalam gelombang pembaruan Islam di Sumatera Barat sejak akhir abad ke-18. Seruan kembali kepada syari'at yang digemakan oleh pengikut tarekat di Timur Tengah dan anak benua India, juga menemukan momentumnya pada surau di Sumatera Barat. Momentum pembaruan ini menjadi kuat dengan terbukanya kontak dengan Mekah dan Madinah. Surau Syattariyah di bawah bimbingan Syaikh Burhanuddin muncul usaha-usaha membangkitkan kembali penekanan pada syari'at seperti yang diberikan gurunya Syaikh Abdurrauf Singkil di Aceh. Usaha-usaha itu diwujudkan dengan menekankan pentingnya pelajaran fikih, Alquran, dan hadis dalam pendidikan surau (Samad, 2003:3). 
Bersamaan dengan itu, surau kemudian berkembang menjadi pusat tarekat. Setiap ulama di Minangkabau memiliki surau sendiri, baik sebagai tempat pengajaran agama maupun tarekat. Eksistensi surau bukan hanya menunjukan suatu jenis lembaga pendidikan masyarakat, tetapi lebih dari itu menunjukan bentuk tarekat yang dianut oleh masyarakat Sumatera Barat. Bahkan, fungsi surau terkadang lebih dominan sebagai tempat praktik tarekat, ketimbang sebagai lembaga pendidikan. Setiap surau memiliki kekhususan tersendiri, baik dalam praktik tarekat maupun penekanan cabang otoritas ilmu-ilmu keislaman.

Masa berikutnya, surau Syaikh Burhanuddin dan surau yang didirikan oleh murid-muridnya berfungsi sebagai pusat tarekat Syattariyah di Sumatera Barat. Di samping itu, sekitar paruh pertama abad XVII muncul pula beberapa surau di pedalaman Sumatera Barat yang menjadi pusat pengembangan tarekat Naqsyabandiyah seperti, di daerah Lima Puluh Kota, Payakumbuh dan Tanah Datar, Batusangkar. Di daerah Pesisir dan Agam terdapat pula surau tarekat Qadiriyah, tetapi tidak begitu dikenal.

Pada perkembangan berikutnya, keberadaan tarekat Naqsyabandiyah di Sumatera Barat kurang "disenangi” oleh penganut tarekat Syattariyah yang lebih dahulu ada. Di antara kedua golongan ini terjadi polemik perbedaan paham keislaman. Hal ini sesuai dengan yang dikemukakan Schrieke (1973:25) bahwa, pada awal abad ke-19, ketegangan antara tarekat Syattariyah dan tarekat Naqsybandiyyah memang tak terhindarkan. Bahkan, pertentangan antara kedua kelompok tarekat tersebut pada gilirannya menjadi bagian dari faktor penyebab munculnya konflik sosial di Sumatra Barat, di samping juga faktor lainnya seperti konflik antara ulama tua dan ulama muda. Berkaitan dengan konflik antara tarekat Syattariyah dengan tarekat Naqsybandiyyah ini, Dobbin (1992:148) misalnya mencatat terjadinya pertentangan sengit yang menyebabkan permusuhan terbuka antara pusat Syattariyah di Ulakan dengan Taram dan Talawi yang berorientasi pada tarekat Naqsybandiyyah.

Tetapi, sejauh menyangkut ketegangan tersebut, tampaknya yang menjadi pangkal utamanya bukan semata-mata persoalan perbedaan paham dan ajaran, melainkan juga dipengaruhi oleh masalah rebutan pengaruh dan kehormatan (Dobbin 1992:148). Beberapa sumber misalnya menginformasikan bahwa Syaikh 
Jalaluddin, seorang Syaikh tarekat Naqsyabandiyyah paling berpengaruh dari Cangking telah berhasil menarik perhatian sejumlah pengikut tarekat Syattariyah di Ulakan untuk berpindah menjadi pengikut tarekat Naqsybandiyyah. Hal ini tentu saja mengakibatkan terjadinya konflik terbuka antara guru-guru tarekat Naqsyabandiyyah dengan guru dari tarekat Syattariyah (Bruinessen 1996:125).

Tentu saja, persoalan yang menyangkut perbedaan paham dan ajaran juga menjadi salah satu pemicu terjadinya ketegangan tersebut. Ini pun dengan catatan bahwa, sejauh data yang dijumpai, hal yang dipertentangkan itu bukan menyangkut doktrin-doktrin tasawuf itu sendiri, melainkan lebih berorientasi pada aspek syariat.

Di antara persoalan yang sering menjadi arena perdebatan antara tarekat Naqsybandiyyah dengan Syattariyah adalah menyangkut penetapan awal dan akhir bulan puasa Ramadan. Schrieke misalnya melaporkan bahwa, selama bertahun-tahun di sekitar Padang Panjang selalu terjadi pertentangan sengit antara Syattariyah dan Naqsyabandiyyah menyangkut persoalan tersebut. Demikian halnya di Pariaman, hingga sekarang masih terjadi perbedaan pendapat antara penganut tarekat Syattariyahdi Ulakan dengan penganut Naqsyabandiyyah di Cangking mengenai awal dan akhir bulan puasa. Biasanya, para penganut Syattariyah merayakan puasa Ramadan pada dua hari kemudian setelah para penganut tarekat Naqsybandiyyah merayakannya, sehingga mereka mendapatkan julukan "orang puasa kemudian", sementara tarekat Naqsybandiyyah disebut orang sebagai "orang puasa dahulu". Hal ini persis seperti apa yang digambarkan dalam kutipan: "...bilangan bulannya bernama bilangan lima yang dua hari dahulunya dari bilangan takwim yang dibawa Syaikh Burhanuddin...".

Selain dalam konteks pertentangan dengan tarekat Naqsyabandiyyah, khususnya dalam persoalan penetapan awal puasa Ramadan, dalam konteks gerakan pembaruan ini pula kiranya kita dapat menempatkan naskah Risâlah Mizân al-Qalb dan naskah Kitâb al-Takwîm wa al-S $\square$ iyâm sebagai naskah yang penting. Dalam Risâlah Mizân al-Qalb, dijelaskan seperti berikut ini.

Adapun sebabnya maka disusun buku ini adalah berkehendak setengah saudara kita untuk memberi penjelasan tentang adanya dua paham untuk beramal ibadat kepada Allah, yaitu disebut orang Kaum Tuo (kaum kuno) dan Kaum Mudo (kaum baru) sehingga kami orang 
awam merasa ragu-ragu manakah yang akan diikuti...Oleh karena kita banyak membaca buku-buku sejarah dan buku hadis, maka dapatlah saya mengabulkan kehendak saudara-saudara kita itu barang alakadarnya (Amin, 1989:3).

Naskah Kitâb al-Taqwîm wa al-S $\square$ iyâm sendiri secara panjang lebar menjelaskan bahwa, kendati metode hisâb taqwim merupakan ajaran nabi dalam menentukan awal bulan Kamariah, tetapi khusus untuk bulan Ramadan, nabi memberikan tuntunan tersendiri, yaitui dengan metode ru'yat al-hilâl (melihat bulan). Dalam konteks Sumatera Barat, hal ini tentu saja ditujukan untuk menyanggah pendapat para penganut tarekat Naqsyabandiyyah, yang tetap berpegang pada metode hisâb taqwîm untuk menentukan awal hari semua bulan Kamariah, termasuk awal hari bulan puasa Ramadan, sehingga selalu terjadi perbedaan di antara keduanya hingga hari ini.

Penting dikemukakan bahwa dalam keseluruhan perdebatan yang melibatkan tarekat Syattariyah tersebut, naskah Risâlah Mizân al-Qalb dan naskah Kitâb al-Taqwîm wa al-S $\square$ iyâm cenderung menegaskan bahwa hingga beberapa puluh tahun lamanya, corak ritual dan ibadah yang dikembangkan oleh para ulama Syattariyahlah yang pada akhirnya diterima oleh masyarakat Minangkabau. Naskah Risâlah Mizân al-Qalb misalnya mengatakan:

...di waktu itu, yaitu di tahun 1840 M sampai tahun 1908 M, seluruh Nusantara ini (Indonesia) satu saja coraknya amal orang, yaitu kalau sembahyang sama-sama berushali, sama berqunut tampung tangan, kalau kematian sama dibacakan talkin, kalau tiba bulan rabiul awwal sama-sama memperingati maulid Nabi Muhammad Saw beserta jamuannya...kalau kematian di rumah seseorang, maka datanglah guru-guru beserta rakyat menghadiahkan bacaan-bacaan amal, seperti membaca al-Quran bertahlil, dan lain-lain amal, waktu memasuki puasa dan akan berhari raya sama-sama memakai rukyat, artinya melihat awal bulan, dan sembahyang tarawihnya dua puluh rakaat, tidak ada yang membuat delapan rakaat... (Amin, 1989:80).

Akan tetapi, rupanya pergolakan keagamaan yang melibatkan kelompok tarekat Syattariyah ini meruncing kembali pada awal abad ke-20, tepatnya ketika pada sekitar tahun 1906 empat ulama Minangkabau kembali dari Tanah Suci Makkah setelah beberapa tahun belajar agama kepada Syaikh Ahmad Khatib al-Minangkabawi. Keempat ulama itu adalah: Haji Muhammad Jamil Jambek Bukittinggi, Haji Muhammad Taib Umar Sungayang Batusangkar, 
Haji Abdullah Ahmad Padang Panjang, dan Haji Abdul Karim Amrullah Maninjau.

Secara spesifik, keempat ulama pembaru ini memang menyoroti praktik tarekat, khususnya tarekat Syattariyah, yang banyak dianut oleh masyarakat Minangkabau. Mereka menganggap bahwa praktik tarekat tersebut bertentangan dengan ajaran Islam. Dijelaskan oleh pengarang bahwa: "...tarekat itu sudah menjadi perbincangan mereka dengan guru mereka bahwa tarekat itu adalah salah..." (Amin, 1989:84). Oleh karena itu, keempat ulama ini sangat proaktif mengajak kepada kalangan penganut tarekat Syattariyah untuk meninggalkan praktik keberagamaannya.

Di samping itu, selain terjadi perdebatan dan polemik keagamaan antara kedua golongan tersebut di tas, perdebatan dan polemik juga terjadi antar sesama penganut tarekat Syattariyah di Minangkabau misalnya, tentang riwayat Syaikh Abdurrauf dan tentang penentuan awal dan akhir bulan Ramadan. Perdebatan dan polemik yang menyangkut riwayat Syaikh Abdurrauf salah satunya adalah tentang lokasi pemakaman Syaikh Abdurrauf al-Sinkili. Dalam naskah yang ditulis oleh Imam Maulana Abdul Manaf Amin alKhatib, lokasi tempat al-Sinkili mengajar hingga wafatnya tersebut adalah di Kuala. Akan tetapi, dalam naskah-naskah versi lain-seperti naskah yang ditulis oleh Angku Sidi Jumadi dan naskah yang ditulis Ambas Mangkuto-disebutkan bahwa lokasi al-Sinkili mengajar hingga wafatnya tersebut adalah di Sigli, Aceh.

Kontroversi tersebut menimbulkan perbedaan pula dalam melakukan ziarah ke makam Syaikh Abdurrauf. Sebagian penganut tarekat Syattariyah di Minangkabau yang mempercayai bahwa Syaikh Abdurrauf dimakamkan di Kuala akanbeziarah ke Kuala, dan sebaliknya, mereka yang mempercayai bahwa Syaikh Abdurrauf dimakamkan di Sigli, akan berziarah ke Sigli, Aceh.

Perdebatan dan polemik yang lain adalah berkenaan dengan salah satu ajaran Syaikh Abdurrauf yang di bawa oleh Syaikh Burhanuddin Ulakan, yaitu ajaran tentang $h \square i s a ̂ b$ taqwîm. $H \square$ isâbtaqwîm adalah salah satu ajaran yang dipelajari dan diamalkan oleh golongan penganut tarekat Syattariyah. Penerapan hisab ini salah satunya untuk menentukan awal puasa Ramadan yang dilakukan dengan melihat bulan (ru'yat al-hilâl). Dalam penerapannya, penganut tarekat Syattariyah di Koto Tangah, Padang memulainya pada hari 
Rabu. Oleh karena itu, penganut ini disebut juga pengamal bilangan Arbai'yah. Sedangkan penganut tarekat Syattariyah yang lain memulai menentukan melihat bulan pada hari Kamis atau penganut bilangan Khâmisi'yah.

Dalam konteks perdebatan paham keislaman tersebut di atas, Imam Maulana Abdul Manaf Amin al-Khatib dan syaikh-syaikh yang lain mencoba meluruskan sejarah dengan jalan menulis naskah. Dalam naskah-naskah itu, mereka secara berulang-ulang, ia menyangkal pendapat-pendapat yang dianggapnya tidak benar, dengan berbagai argumen yang menurutnya tidak memiliki dasar yang jelas.

\section{Faktor Kondisi Sosial-Politik Semasa}

Naskah-naskah karya para syaikh di surau-surau di Padang dan Padang Pariaman, khususnya yang ditulis oleh Imam Maulana Abdul Manaf Amin al-Khatib ditulis dalam empat masa: masa penjajahan, masa Orde Lama, Orde Baru, dan Orde Reformasi. Dari teks-teks yang dikandung dalam naskah-naskah itu tampak bahwa kondisi sosial-politik semasa ikut mempengaruhi pandangan ideologis, baik ulama tarekat Syattariyah di Koto Tangah, Padang maupun penulisnya. Akan tetapi, kondisi sosial-politik di masa penjajahan yang lebih mempengaruhi pandangan ideologis dalam naskah-naskah itu.

Pada masa penjajahan, Pemerintah Belanda mengerahkan beberapa orang sarjananya untuk mengadakan penelitian tentang tarekat yang ada di Sumatera Barat. Salah seorang di antaranya adalah Dr. Ph. S. Van Ronkel. Ronkel dalam Latief (1988:210) antara lain menyebutkan dalam laporannya pada tahun 1916 bahwa, bahaya dari aliran-aliran tarekat bukanlah terletak pada unsur kefanatikannya, melainkan terletak pada kepatuhan yang mutlak dari para anggotanya kepada pada syaikh yang memang menuntut kepatuhan itu sebagai haknya.

Khusus mengenai kaum Syattariyah, Ronkelmenyebutkan bahwa, para pemimpin tarekat Syattariyah itu biasanya adalah orangorang yang tangguh pengetahuannya, menjadi lawan bagi setiap aliran lainnya, dan suka mengejar-ngejar kekuasaan. Dengan demikian, tidak jarang merupakan sesuatu yang amat berbahaya bagi pemerintahan Belanda. Apabila terdapat kejadian-kejadian tertentu yang mereka cetuskan, dapat mengganggu kelancaran pemerintahan Belanda 
nantinya. Karena ancaman tersebut, Pemerintah Belanda membuat strategi khusus untuk mengantisipasi potensi perlawanan dari kaum tarekat di Sumatera Barat. Dalam konteks ini, setidaknya ada dua strategi yang dibuat oleh Pemerintah Belanda, yaitupertama, mengadakan pengawasan yang ketat terhadap segala aktivitas yang dilakukan oleh kaum tarekat (Syattariyah). Dalam hal ini Pemerintah Belanda menempatkan seorang pengawas kelas tiga yang punya latar belakang ilmu Budaya. Belanda menempatkan seorang posthouder di Ulakan sejak tahun 1844 (Suryadi, 2004:117 \#92); dan kedua, dengan mendekati, membujuk, dan memuji-muji para guru tarekat, dengan harapan agar mereka lebih memusatkan perhatian pada aktivitas kesufian dan menjauhi urusan keduniaan. Dengan demikian, semangat jihad mereka yang sering menggangu kolonial akan dapat diredam. Sementara itu, tokoh-tokoh tarekat yang dianggap berbahaya dan tidak mempan dibujuk akan diusir dari daerah ini atau dibunuh dengan berbagai cara yang licik.

Untuk kasus pusat tarekat Syattariyah di Ulakan Pariman, agaknya strategi Belanda ini berhasil. Hal ini dapat dicermati pada paroh pertma abad ke-19, di mana banyak pengikut tarekat Syattariyah di Ulakan Pariaman terpengaruh oleh gerakan pembaruan Islam di Sumatera Barat. Golongan penganut tarekat Syattariyah yang terpengaruh oleh ide-ide pembaruan itu karena tidak puas dengan ulama Ulakan yang dinilai tidak memiliki komitmen untuk memerangi Belanda. Apalagi dalam kenyataanya Ulakan sebagai salah satu pusat tarekat Syattariyah tidak pernah benar-benar menunjukkan penentangannya atau setidaknya bersikap tegas terhadap Belanda yang dianggap kafir. Boleh jadi karena sifat tarekat Syattariyah (di Ulakan) yang suka pada harmoni, menyebabkan mereka cenderung menghindari konfrontasi dengan Belanda (Suryadi, 2004:117).

Kondisi di atas sangat berbeda dengan ulama-ulama tarekat Syattariyah di Koto Tangah, Padang. Di wilayah ini Belanda mendapat perlawanan yang keras dari mereka. Gambaran perlawanan ulama tarekat Syattariyah tersebut dapat ditemui dalam teks SejarahSurau Baru dan teks Sejarah Syaikh Paseban.

Dalam teks Sejarah Syaikh Surau Baru misalnya, diceritakan tentang pemberontakan rakyat Koto Tangah dan Pauh, Padang kepada Belanda di bawah pimpinan Pakih Mudo. Pakih Mudo adalah murid Syaikh Surau Baru yang diutus untuk mengislamkan rakyat Pauh, 
Lubuk Begalung dan sekitarnya. Ketika rakyat Koto Tangah dan Pauh, Padang berperang dengan Belanda yang dibantu oleh orang Kota Padang, maka Pakih Mudo mengomando rakyat Koto Tangah dan Pauh dalam peperangan itu.

Peperangan itu menyebabkan Syaikh Surau Baru ditawan Belanda. Penawanan itu dilaksanakan dengan alasan bahwa Pakih Mudo adalah murid Syaikh Surau Baru. Perang terjadi atas komando dan dorongan Syaikh Surau Baru. Dalam masa tawanan itulah Syaikh Surau Baru wafat dan tidak ada lagi yang melawan Belanda hingga ratusan tahun kemudian, yaitu perlawanan ke Belanda yang dinamakan Perang Paderi yang dipimpin oleh Imam Bonjol. Kisah ini dapat ditemukan dalam kutipan teks berikut ini:

Beginilah riwayat ringkas perjalanan hidup beliau Tuan Syaikh Surau Baru yang telah mengislamkan Koto Tangah, Pauh, dan sekitarnya. Juga beliaulah, Syaikh Surau Baru yang mula-mula melawan penjajah Belanda yang akan menginjakkan telapak kakinya di Pantai Minangkabau pada tahun 1658 Masehi (1076 Hijrat) yang bermaksud menjajah Minangkabau ... terjadi berkali-kali peperangan di Pauh dan Koto Tangah antara rakyat dengan tentara Belanda yang dibantu oleh laskar Padang yang telah takluk di bawah kekuasaan kompeni Belanda. Setelah Syaikh Surau Baru wafat ditawan kompeni Belanda barulah habis perlawanan rakyat terhadap kompeni Belanda. Maka amanlah Belanda di Padang sampai 170 tahun kemudian barulah ada kembali perlawanan terhadap Belanda yang (di)kepalai oleh Tuanku Imam Bonjol yang dinamai Perang Paderi mulai tahun 1803 berakhir tahun 1837 (Amin, t.th.: 51-52).

Selain Syaikh Surau Baru, perlawanan terhadap Belanda juga dilakukan oleh ulama tarekat Syattariyah di Koto Tangah, Padang yaitu, Syaikh Paseban. Perlawanan Syaikh Paseban. pada waktu itu adalah dengan tidak bersedia membayar pajak kepada pemerintahan Belanda di Kota Padang. Karena perbuatannya tersebut, ia ditangkap dan dipenjarakan oleh Belanda. Selain itu, pernah suatu kali Belanda dengan taktiknya akan memberikan penghargaan kepada Syaikh Paseban. Penghargaan tersebut berupa bintang jasa yang oleh Belanda dikatakan bahwa Syaikh Paseban berhak menerima karena ia adalah ulama besar yang telah banyak berjasa bagi kaumnya. Akan tetapi, penghargaan itu ditolah oleh Syaikh Paseban. "Yang akan memberi saya bintang adalah Tuhan, tidak Belanda, "kata Syaikh Paseban (Amin, 2001:29, 34). 
Dalam konteks perlawanan tersebut, dalam naskah Sejarah Ringkas Syaikh Paseben Asyattari Rahimahullah Taala Anhu, penulisnya kembali menegaskan tentang kepahlawanan Syaikh Surau Baru. Dalam salah satu bagian teks disebutkan bahwa Syaikh Paseban selalu mengadakan ziarah ke makam Syaikh Surau Baru di Batusingka, Air Dingin, Koto Tangah, Padang. Ziarah tersebut ia lakukan karena,

...(kedua) adalah di suatu makam Syaikh Muhammad Natsir (Syaikh Surau Baru). Syaikh Surau Baru ini adalah orang Kota Panjang, Kota Tengah, Padang. Beliau sama pergi menuntut ilmu dengan Syaikh Burhanuddin ke Aceh kepada Syaikh Abdurrauf (Syaikh Kuala). Beliaulah, Syaikh Surau Baru inilah yang mengislamkan Negeri Kota Tengah, Pauh, Lubuk Bagalung (Negeri yang dua puluh) dan Negri Padang. (ketiga) Jasa beliau Syaikh Surau Baru, beliaulah yang mulanya melawan Belanda di Minangkabau ini, 170 tahun (seratus tujuh puluh tahun) sebelum Tuanku Imam Bonjol. Syaikh Surau Baru melawan Belanda waktu Belanda akan menjejakkan kakinya di Pantai Padang sedangkan Tuanku Imam Bonjol mengusir Belanda yang telah menduduki Minangkabau. Itu perbedaan perjuangan Syaikh Surau Baru dengan Syaikh Paseban. Beliau Syaikh Surau Baru dapat ditawan Belanda dimasukkannya ke dalam rajam dan wafat di situ dan Tuanku Imam Bonjol ditawan Belanda dibuangnya ke Manado dan wafat di situ (Amin, 2001:39).

Agaknya penulis naskah ingin mempertegas bahwa Syaikh Surau Baru, ulama tarekat Syattariyah di Koto Tangah, Padang adalah benar-benar berjiwa pahlawan. Hal ini juga sekaligus mempertegas bahwa ulama tarekat Syattariyah di Koto Tangah, Padang selain orang alim juga anti penjajah. Oleh karena itu, pengikutnya harus menghormatinya agar memperoleh berkah.

Setelah Indonesia merdeka, Wakil Presiden Republik Indonesia, M. Hatta, memaklumatkan agar menumbuhkan berbagai organisasi dan partai. Hal ini untuk menolak tudingan Belanda bahwa Indonesia bukanlah negara yang sah. Setelah adanya maklumat ini, maka banyaklah lahir parta-partai di negeri ini, termasuk juga di Sumatera Barat (Nasution, 2002: 899). Salah satu organisasi sosial yang berikutnya menjadi sebuah partai di Sumatera Barat adalah Persatuan Tarbiyah Islamiyah (Perti). Pada awalnya, Perti adalah organisasi sosial yang didirikan pada tanggal 5 Mei 1930 di Candung, Bukittinggi. Pendirinya adalah para ulama yang terdiri dari Syaikh 
Sulaiman ar-Rasuli Candung, Syaikh Muhammad Abbas al-Kadi, Bukittinggi, Syaikh Muhammad Jamil Jaho Padangpanjang dan Syaikh Abdul Wahid, Tabekgadang. Perti mengikuti aliran Ahlul Sunnah wal Jamaah dalam itikad dan mazhab Syafi'i dalam syariat dan ibadat. Sejak 22 Nopember organisasi sosial ini berubah menjadi partai politik dengan nama Partai Politik Islam Perti (Nasution, 2002:899).

Menarik dikemukakan bahwa menjelang Pemilihan Umum pertama tahun 1955 — saat di mana masing-masing partai gencar berkampanye mencari dukungan - terjadi ketegangan hubungan antara Imam Maulana Abdul Manaf Amin al-Khatib dengan Angku Talaok akibat perbedaan pilihan partai di antara mereka (Amin, 2002:47-57). Di satu sisi, Angku Talaok bergabung dengan Partai Islam Indonesia (PII), sementara di sisi lain, Imam Maulana Abdul Manaf Amin menjadi anggota Partai Islam Perti. Pada awal tahun 1950-an Angku Talaok pernah diminta oleh para penganut tarekat Syattariyah di Batang Kabung dan sekitarnya untuk membantu mengajar di beberapa surau mereka. Saat itu, yang telah lebih dahulu mengajar di surau Batang Kabung, dan beberapa surau lain di sekelilingnya, adalah Imam Maulana Abdul Manaf Amin.

Polemik tentang partai juga dialami oleh Imam Maulana Abdul Manaf Amin al-Khatib di era Orde Baru. Ia pernah bersilang pendapat dengan Angku Inyik Adam, khalifah tarekat Syattariyah dari Syaikh Paseban, yang sebetulnya merupakan kawan seperguruan Imam Maulana Abdul Manaf Amin al-Khatib sendiri ketika belajar dengan Syaikh Paseban. Saat itu, Angku Inyik Adam mengajaknya untuk masuk ke dalam partai Golkar, agar mudah mendapat bantuan dari Pemerintah untuk renovasi makam Syaikh Surau Baru di Batusingka, Koto Tangah, Padang. Akan tetapi, ajakan itu ditolak oleh Imam Maulana Abdul Manaf Amin. Dalam hal ini menarik disimak penolakan ajakan untuk masuk ke partai Golkar oleh Angku Inyik Adam berikut ini.

Begini Inyik, adapun Beliau ini (Syaikh Surau Baru -pen.) bukan orang partai, bukan pula ziarah bersama ini (bersyafar) tidak atas nama partai. Bersyafar ini adalah atas nama kaum muslimin, tidak dihitung partainya ... Kalau saya masuk Golkar berarti ziarah bersama (bersyafar) ini tentu Syafar orang Golkar kata orang (Amin, 2002:63). 
Penting dikemukakan di sini bahwa banyak dan bahkan sebagian besar pengikut tarekat Syattariyah di Sumatera Barat yang masuk ke partai Gokar setelah Perti kembali berstatus organisasi nonpolitik. Perti mengalami perpecahan di dalam tubuh organisasinya karena ada pro dan kontra terhadap gagasan Nasakom yang dicetuskan oleh Soekarno. Kemelut yang kurang terbenahi ini sangat merugikan tujuan semula organisasi. Pengelolaan bidang pendidikan dan dakwah seolah-olah terlupakan kalau tidak dapat dikatakan terabaikan sama sekali. Oleh karena itu, pada tahun 1969, Syaikh Sulaiman ar-Rasuli, pendiri organisasi ini yang masih hidup pada waktu itu, mendekritkan agar kembali kepada khittah semula, yaitu status nonpol, bergerak di bidang sosial. Dekrit ini hanya diterima oleh sebagian saja yang dipimpin oleh putranya K.H. Burhanuddin ar-Rasuli, dan kemudian dalam menyalurkan aspirasi politiknya bergabung dengan Golkar.

\section{Faktor Pendidikan Surau}

Surau sebagai tempat penulisan dan penyalinan naskah merupakan fenomena yang menarik sebagai gambaran tradisi pernaskahan di Minangkabau. Lebih menarik lagi, tradisi pernaskahan tersebut masih berlangsung hingga menjelang akhir tahun 2006 seperti yang dilakukan oleh Imam Maulana Abdul Manaf Amin al-Khatib yang menjadi sumber utama dalam penelitian ini.

Sistem pendidikan ini cukup memberi pengaruh terhadap pemikiran para ulama yang mengenyamnya. Dalam sistem pendidikan surau tidak dikenal tingkatan atau kelas khusus. Sistem pendidikan surau, sangat tergantung kepada keahlian dan intelektual yang dimiliki oleh syaikh, ungku, dan buya yang mengejar. Pendidikan yang disampaikan tidak skriptualisme saja, tetapi juga berkaitan erat dengan aktualisasi skriptual. Bahkan diajarkan beragam aspek pendidikan, termasuk masalah adat istiadat dan ilmu kecakapan lainnya.

Secara sederhana, dapat disebutkan bahwa ada tiga bentuk sistem pengajaran agama Islam dilaksanakan di surau, yaitupertama, dilakukan dengan sederhana dengan cara memperkenalakan skriptualisme (wahyu) secara tektual. Agama Islam dalam konteks ini hanya baru dipahami sebagai tekstualitas. Tahap ini dinamakan dengan tahap pengenalan agama;kedua, tahap penjelasan, yaitu seorang guru memulai menjelaskan tekstualitas wahyu kedalam kontekstualitas; danketiga, memodernisasi pengajaran Islam dengan 
mengadopsi sistem pendidikan yang berkembang di luar konteks lokal.

Metode utama yang digunakan dalam proses pengajaran adalah pemberian ceramah, membaca, dan menghafal. Jelas syaikh atau guruguru tidak menggunakan metode pembelajaran yang dapat merangsang urang siak atau pakih berpikir secara kritis dan analisis. Pelajaran diberikan dengan memakai metode halaqah, yaituurang siak duduk di atas lantai dalam suatu lingkaran di sekitar syaikh atau guru yang memberikan pelajaran. Dengan metode ini, seorang syaikh atau guru membaca dan menjelaskan isi suatu kitab dalam lingkaran muridmuridnya, sementara para murid memegang bukunya sendiri mereka membuat catatan pada sisi halaman kitab atau dalam buku catatan khusus.

Untuk kasus surau tarekat Syattariyah, urang siak yang belajar di surau ini cenderung diekspos pada pengajaran Islam secara keseluruhan. Menariknya, terdapat beragam surau tarekat Syattariyah yang mengambil spesialisasi dalam cabang pengajaran Islam yang berbeda-beda. Misalnya, Surau Kamang spesialisasinya dalam ilmu alat (studi mengenai bahasa Arab dan subjek-subjek yang terkait); Surau Koto Gadang dalam ilmu mantiq ma'ani (ilmu logika); Surau Sumanik dalam studi hadits, tafsir, dan fara'id dan lain-lain (Azra, 2003:99-100).

Pada umumnya, permulaan semua pengajaran di surau adalah membaca Alquran atau disebut juga belajar surat alif atau surat 'amma. Pada tahap ini urang siak diajarkan cara membaca Alquran dengan aturan-aturan di dalamnya dan dengan sedikit penekanan dan pemahaman. Pada tahap berikutnya, bagi urang siak yang ingin mempelajari Alquran dengan penekanan dan pemahaman yang lebih, maka harus mempelajari bahasa Arab dengan serangkaian teks gramatikal. Tahap ini merupakan tahap yang panjang dan tahap sulit yang dihadapi oleh banyak urang siak. Setelah penguasaan bahasa Arab, maka pada tahap berikutnya dapat melangkah kepada pelajaran dan kajian syariat, biasanya disebut fiqih dan cabang ajaran-ajaran Islam yang lainnya. Tidak banyak urang siak yang mau dan mampu berlanjut ke tahap pengajaran ini.

Pada tahap yang terakhir itu, khususnya di surau tarekat Syattariyah, ada hal yang penting yang harus dilakukan oleh urang siak kepada syaikh atau guru yang mengajar di suatu surau. Setiap 
murid yang akan memasuki atau "memperdalamkaji" tarekat Syattariyah harus melakukan bai'ah terlebih dahulu kepada syaikh atau guru. Bai'ah ini dimaksudkan untuk mengadakan janji setia antara guru dan murid. Bai'ah biasanya dilakukan pada malam hari di surau tempat syaikh atau guru mengajar. Pelaksanaan bai'ah adakalanya berlangsung antara murid dengan guru saja, tetapi ada juga yang dilakukan secara bersama-sama dengan dengan murid yang lain yang akan menghadakan bai'ah.

Adanya bai'ah ini menimbulkan kewajiban moral pada setiap murid untuk mempunyai kesetiaan yang mutlak terhadap gurunya. Tidak boleh satu janji pun dilanggar oleh para murid. Kemudian, pada gilirannya, kesetiaan itupun melahirkan suasana yang penuh kerahasiaan, sehingga tak satupun rahasia guru yang diketahui oleh murid tersebut akan sampai kepada orang lain.

Dari pendidikan surau tersebut para syaikh di surau-surau di Padang dan Padang Pariaman bisa menulis banyak naskah. Naskahnaskah yang ditulisnya, dengan demikian, juga dipengaruhi oleh proses pendidikannya itu. Pengaruhnya terlihat misalnya, tentang uraiannya yang berulang kali tentang penghormatan terhadap guru, tentang penggunaan kitab-kitab berbahasa Arab yang menjadi rujukan dalam penulisan beberapa naskah, termasuk tentang penggunaan aksara Jawi dalam menuliskan teks-teks yang mereka akan tulis.

\section{PENUTUP}

Dari uraian yang telah dijabarkan di atasdapat disimpulkan ke dalam beberapa hal berikut. Kesimpulan ini merangkum sejumlah pokok pikiran yang berhasil dimunculkan dari sejumlah data dan fakta yang berkaitan dengan segi tekstual maupun kontekstual karya yang dibicarakan.

Pertama, surau-surau (khususnya surau tarekat Syattariyah) yang ada di Padang dan Padang Pariaman pernah ada tradisi penulisan naskah. Hingga saat ini beberapa surau di antaranya masih terdapat tradisi pernaskahan. Naskah-naskah yang ada masih dijadikan rujukan da pedoman dalam beribadah dan dalam kehidupan sehari-hari.

Kedua, naskah-naskah yang ditemukan di surau-surau di Padang dan Padang Pariaman kebanyakan ditulis karena banyak permintaan dari kalangan tarekat Syattariyah. Di samping itu, naskahnaskah itu ditulis karena untuk menghormati para syaikh dengan 
tujuan memperoleh berkah. Oleh karena itu, naskah tersebut juga dimaksudkan untuk menyatakan bahwa ajaran para syaikh itu benar adanya dan kritikan dari pihak luar adalah salah. Dengan demikian, secara kultural hal ini memperlihatkan bahwa di tengah masyarakat (khususnya para penanut paham tarekat Syattariyah) ada keperluan akan "kitab" itu. Hal ini bekaitan dengan kepercayaan bahwa mengetahui, memiliki bukunya, ataupun mendengar riwayat ulama, guru, dalam paham tarekat Syattariyah itu penting.

Ketiga, dalam tulisan sejarah para syaikh dan ajarannya dapat ditemukan pandangan-pandangan ideologis pengarangnya. Pandangan-pandangan ideologis tersebut dipengaruhi oleh: 1) faktor perbedaan paham keagamaan yang melahirkan "gerakan" untuk mempetahankan paham keagamaan sendiri bahwa, pahamnya benar dan ali serta berdasar; 2) faktor sosial-budaya Minangkabau, yang memberi ruang masyarakatnya untuk senantiasa berkonflik; 3) faktor sosial-politik semasa seperti, penjajahan dan kemerdekaan yang ikut mewarnai pemikiran ulama tarekat Syattariyah; dan 4) faktor pendidikan surau.

\section{DAFTAR PUSTAKA}

Amin, Imam Maulana Abdul Manaf.. 1936. Inilah Sejarah Ringkas Auliyaullah al-Salihin Syaikh Burhanuddin Ulakan yang Mengembangkan Agama Islam di Daerah Minangkabau, naskah tulisan tangan koleksi Imam Maulana Abdul Manaf Amin, Batang Kabung, Koto Tangah, Padang Sumatra Barat.

.1986. Kitâb al-Taqwîm wa al-S $\square$ iyâm, naskah tulisan tangan koleksi Imam Maulana Abdul Manaf Amin, Batang Kabung, Koto Tangah, Padang Sumatra Barat.

.1989. Risâlah Mizân al-Qalb. naskah tulisan tangan koleksi Imam Maulana Abdul Manaf Amin, Batang Kabung, Koto Tangah, Padang Sumatra Barat.

.T.th. Sejarah Ringkas Shaikh Muhammad Nasir (Syaikh Surau Baru). naskah tulisan tangan koleksi Imam Maulana Abdul Manaf Amin, Batang Kabung, Koto Tangah, Padang Sumatra Barat.

.2001. Sejarah Ringkas Syaikh Paseban al-Syatari Rahimahulallahu Taala. naskah tulisan tangan koleksi Imam Maulana Abdul Manaf Amin, Batang Kabung, Koto Tangah, Padang Sumatra Barat. 
.2002. Kitab Riwayat Hidup Imam Maulana Abdul Manaf Amin. naskah tulisan tangan koleksi Imam Maulana Abdul Manaf Amin, Batang Kabung, Koto Tangah, Padang Sumatra Barat

Azra, Azyumardi. 2003. Surau: Pendidikan Islam Tradisional dalam Transisi dan Modernisasi. Jakarta: Logos Wacana Ilmu.

Bruinessen, Martin van. 1996. Tarekat Naqsyabandiyah di Indonesia. Cet. ke-4. Bandung: Mizan.

Dobbin, Christine. 1992. Kebangkitan Islam dan Ekonomi Petani yang Sedang Berubah: Sumatra Tengah, 1784-1847.Terjemahan oleh Lillian D. Tedjasudhana. Jakarta: INIS.

Latief, M. Sanusi. 1988. Gerakan Kaum Tua di Minangkabau. Disertasi tidak diterbitkan. Yogyakarta: Fakultas Sastra Universitas Gajahmada.

Nasution, Harun (Ketua Tim). 2002. Ensiklopedi Islam Indonesia.Jilid 3 OZ. Jakarta : Djambatan.

Pramono. 2005. Tradisi Intelektual Keislaman Minangkabau: Kajian Teks dan Konteks Terhadap Karya-Karya Imam Maulana Abdul Manaf Amin Al-Khatib. Makalah disajikan dalamSeminar Filologi di Wisma Ciloto, Jawa Barat, Tanggal 24-26 Januari 2005.

. 2006. Tradisi Penulisan dan Penyalinan Naskah-Naskah Islam Minangkabau: Kajian Atas Imam Maulana Abdul Manaf Amin AlKhatib dan Karya-Karyanya. Laporan Penelitian. Padang: Fakultas Sastra Unand.

Putra, Yerry Satria. 2003. Transliterasi dan Analisis Teks Sejarah Ringkas Syaikh Paseban Assyatiari Rahimahulah Ta'ala Anhu. Skripsitidak diterbitkan.Padang: Fakultas Sastra Unand. . 2006. Sejarah Islam Dinamika Pemikiran Keislaman Umat Muslim Sumatera Barat di Abad ke-19: Studi Teks dan Kontekstual Naskah Inilah Sejarah Ringkas Syekh Paseban Assyattari Rahimahullah Taala.Laporan Penelitian. Padang: Lemlit Unand.

Ricklefs, M.C. dan Voorhoeve. 1977. Indonesian Manuscrifts in Great Britain. London : Oxford University Press.

Ronkel, Ph. S van. 1908. Catalogus der Maleisch Handscriften van het Koninklijk Instituut voor Taal-, Land-, en Volkenkunde van Nederlands-Indie. BKI 60: 181-248.

Samad, Duski. 2003. Tradisionalisme Islam di Tengah Modernisme: Kajian tentang Kontinuitas, Perubahan, dan Dinamika Tarekat di Minangkabau.Disertasi tidak diterbitkan. Jakarta: UIN Syarif Hidayatullah.

Schrieke, B.J.O. 1973. Pergolakan Agama di Sumatera Barat: Sebuah Sumbangan Bibliografi.Terjemahan oleh Soegarda Poerbakawatja. Jakarta: Bhratara. 
Sutarga, Amir, dkk. 1972. Katalogus Koleksi Naskah Melayu Museum Pusat Jakarta. Jakarta: Proyek Inventarisasi dan Dokumentasi Kebudayaan Nasional. Direktorat Jenderal Kebudayaan.

Suryadi. 2004. Syair Sunur: Teks dan Konteks Otobiografi Seorang Ulama Minangkabau Abad Ke-19. Padang: Citra Budaya.

Wierenga, E.P. 1998. Catalogue of Malay an Minangkabau Manuscripts in the Library of Leiden University an Other Collections in the Netherlands. Vol. I. Leiden : Legatum Warnerianum in the Library of the University of Leiden.

Zuriati. 2003. Undang-Undang Minangkabau, Pengaruh Tasawuf dan Dinamika Hukum Adat di Bawah Pengaruh Hukum Islam (Syarak), (Suntingan Teks dan Analisis Isi). Tesis tidak diterbitkan.PPs Ilmu Pengetahuan Budaya Universitas Indonesia. Jakarta: Fakultas Ilmu Pengetahuan Budaya UI.

*Versi awal artikel ini adalah artikel hasil penelitian Dosen Muda (BBI) yang dibiayai oleh Direktorat Jenderal Pendidikan Tinggi, Departemen Pendidikan Nasional, dan telah dipresentasikan dalam Seminar Nasional Hasil Penelitian Dosen Muda (BBI) dan Studi Kajian Wanita (SKW) Wilayah Sumbar, Riau, Medan dan Aceh, pada 22-24 Mei 2008 di Padang. 